\title{
Introducing Numerical Concepts through Number Cards for Early Childhood
}

\author{
Aisyah \\ Teacher Education-Early Childhood Education, Faculty of Teacher Training and Education, University of PGRI Adi Buana \\ Surabaya
}

Corresponding e-mail: aisyahbaswedan@yahoo.co.id

\begin{abstract}
Early Childhood Education is one form of organization of education that focuses on the foundation towards growth and physical development (coordination of fine and gross motor), intellect (the intellect, creativity, emotional intelligence, spiritual intelligence), social-emotional (attitude and behavior and religion) language and communication, according to the uniqueness and the developmental stages through which early childhood. Ability to know the basic concept of numbers is the ability to be possessed by any person, including early childhood, because this capability is part of the mathematics required to develop numeracy skills that are useful for everyday life as well as readiness to attend primary school education. Interest introduce learning how to figure the introduction of the concept of early childhood. The method in this conceptual idea is the study of literature. The results of conceptual ideas with the title of the introduction of the concept of numbers with a media card numbers in early childhood is to develop cognitive abilities related to develop the ability to think that children receive the lesson, can mimic a variety of alternative solutions, helps children to develop logic skills math and knowledge space and time, and has the ability to sort, classify and prepare the ability to think carefully. Thus, the authors concluded that the learning concept of numbers by using a media card numbers is a method of learning is very effective and efficient for young children in the early stages of learning to understand the numbers and arithmetic.
\end{abstract}

Keywords: number cards, numerical concepts.

\section{INTRODUCTION}

Early childhood education is a secondary level of basic education before which is a coaching effort shown for children from birth up to the age of six through the awarding of educational stimulation to help the growth and development of physical and spiritual so that children have preparedness in entering further education, which was held on the formal, non-formal, and informal. Early childhood education is a very basic education. This was his second gold age of child development. The granting of the right stimulus would be of capital importance for the child's development. Stimulus given should be able to trigger the development of children's intelligence.

Early childhood education is one form of organizing education that operates on the laying of the basis towards the growth and development of the physical (fine motor coordination and rough), intelligence (intellect, creativity, emotional intelligence, spiritual intelligence), socialemotional (attitudes and behavior as well as religion) language and communication, in accordance with the uniqueness and stages of development undertaken by early childhood. The time of children is the gold. In which this is experienced both emotional development, and social. There are various factors that affect child development. Internal factors that affect child development includes adequate intelligence, self-concept, motivation, interest, achievers include family, school, neighborhood and community environments. Media learning aims to provide basic knowledge and basic skills on learners who have benefits in accordance with the level of its development as well as prepare them for the following education in all schools of a higher level. Associated with the purpose to provide the basic skills learning in particular understanding the concept of numbers in the early childhood education is very important. Using the media of instruction in the form of a media card numbers as a tool that can provide the stimulus nor interest to more interested 
towards the process of learning the concept of numbers.

\section{DISCUSSION}

The learning process of the child be affected by maturity. The child's learning process are influenced by the environment. Not only the physical environment, but also the learning environment. Through play children can understand, create, manipulate, symbols, to transform objects. The development is influenced by factors of maturity and learning. When the child showed sensitive period (maturity) for counting, then parents and teachers in kindergarten should be responsive, to immediately provide services and guidance so that the child's needs can be met and distributed with their best towards the development of an optimal arithmetic.

At the age of 3 to 6 years old children started entering preschool or the formal education. Where the children have sensitive period i.e. the period that must be developed carefully. And it's still a very strong ego its head.

The term cognitive often known as the intellect. The intellect is derived from English "intellect". According to Chaplin (in Asrori, 2007:36) revealed that: "the cognitive processes, thought processes, and assess the capability of connecting power capability considering also the mental ability or intelligence".

The importance of developing cognitive aspects in children is also expressed by Piaget (in Sujiono, et al., 2007:122) stating that the development of cognitive ability in children has the following benefits: 1) so that the child is able to develop its perception power based on what he can see, hear and feel so that the child will have a comprehensive understanding of the whole and, 2) so that the child is able to train her memory to all the events and happenings that have never experienced firsthand , 3) so that the child is able to develop his thoughts in order to connect an event with another event, 4) so that the child understand various symbols are scattered in the surrounding areas, 5) so that the child is able to perform reasoning-good reasoning that happens by the process of natural (spontaneous) or through the scientific process (experimental), 6) so that the child is able to solve the problems facing life so that in the end will be the individual who is able to help himself.

According to Piaget's stages of cognitive development there are four children, namely the following:
1) Sensorimotor Stage, ages 0-2 years;

2) Preoperational Stages, ages 2-7 years;

3) Concrete operational Stage, ages 7-11 years;

4) Formal operational Stage, aged 11 years and over;

Bandi Delphie (2005:75) explains that:

"Activities against the knowledge of motion include activities on cognitive phase- when someone tries to understand something, then this activity appeared - andphases of associative or practice - i.e. activities that relate to the Association or to do certain exercises, this activity is meant to learn certain skills. And the last Is a phase of autonomous, i.e. phase happens immediately after something activities has become a favorite hobby or activity ".

According to Bandi Delphie (2005:79)

"knowledge of the motion is very important in the quest to develop cognitive ability".

Rosmala (2005:21) States that cognitive development of children aged 4-5 years is:

1) call sequence numbers of 1-10,

2) called, pointing and classify 5 colors,

3) rearranges the pieces of the puzzle so that it becomes the shape of the whole,

4) pair of objects according her partner,

5) try and tell me what happens if the colors are mixed, the seeds were planted,

6) balloon is blown and then blew out, the objects entered the water, the objects were dropped, and others,

7) try and tell me what happens, if the small objects in the view with a magnifying glass and if brave iron are brought with a variety of objects made of iron,

8) describes a person with 2-3 parts of the body such as the head, hands, feet,

9) ability to pay attention or concentrate for longer,

10) increase understanding of the functions of experience, time, relationships the part with the whole.

According to Delphie Bandi (2009:4) "Understanding the concept or concepts referring to the planting base. Children develop a concept when child is able to classify or group the objects and be able to associate a name with a particular group of objects ". Thus it can be said that the concept of numbers is the Foundation of mathematics. 
According to Sudaryanti $(2006: 1)$ Number is a mathematical object which is abstract and contains elements that are not defined, then the required symbol or symbol to represent a number. To state the number of the notated with the coat of arms of numbers called numbers. With regard to the number of values. The numbers simply are a written notation of a number.

According to Surviving KW (in Kemendiknas 2011:18) "the most important math concepts studied children aged 3-6 years is the development of sensitivity on numbers, which means more than just counting". The development of number concept of sensitivity in children aged 3-6 years can be done through 3 stages, namely: (1) calculate, calculate the initial stages in children is through the recitation count or to number. (2) one-one Relationship, the intent is to connect one, and one which has to do with numbers. (3) Make, comparing the symbols and numbers. When children are able to pick up objects as requested, then the child can be said to understand about the concept of the number or amount.

The difficulty of understanding the concept of numbers indicated a 5-year old children require guidance and mentoring by the parents (teachers). Parents and teachers are very plays an active role in helping the child to be able to understand the concept of a number. This can be done by parents and teachers through fun activities for the children, for example through a variety of games that are related to the number (Fatimah, 2009:23).

In delivering learning numbers for early childhood, require stages in the delivery, and it is done gradually. There are two ways to enumerate. First, the number of objects by touching it with a finger. Second, it enumerates and shows objects that arguably. The second way is the most appropriate for children is the first way.

Children learn through three phases namely Enactive, the iconic and symbolic. In the first stage of the Enactive children need props. After learning to use concrete objectschildren can learn with the use of pictures and continued with the use of symbols (Fatimah, 2009:23).

One element that exists in mathematics is the ability to enumerate or called numbers with digits, is inseparable from mathematics. The number is part of our lives, every day always finds whose name figures or numbers, these capabilities according to Duslani (in Tajudin,2008) is a good helper tool used in an introduction to the number. By studying the concept of numbers early then the child can:

1. Can think logically and systematically at early stages through observation of concrete objects, pictures or numbers, numbers that there are around children.

2. Can adjust and immerse yourself in the life of the community in need of skills in daily numeracy.

3. Have a precision, concentration, abstraction and the power of appreciation.

4. Have an understanding of the concept of time and space and can estimate the likely sequence of events occurred in the vicinity of something.

5. Has the creativity and imagination in creating something spontaneously.

The traits that mark that children have started enjoying the game counting between other:

1. Spontaneously have showed an interest in the activity of the game count.

2. The child begins to call the sequence of the numbers without understanding.

3. The child begins to count the objects that exist in the surrounding spontaneously.

4. Children start appealing to compare objects and events that are in the vicinity.

5. The child begins to make a-total or reduce the numbers and objects that exist in the vicinity without intentional.

Hurlock (1978) revealed that definition is based on the concept. The concept is not a direct sensory impression, but rather the results of processing and combination, merger, or a mix of the impression of separate senses. The symbolic nature of the concept of cause rely on the nature of the situation at hand as well as other circumstances, and the properties of objects. Along with the development of understanding numbers beginning this, stating that the concept began to grasp the child in line with increasing experience experienced by a child, including the concept of the understanding of numbers, numbers will evolve quickly, after they sit in kindergarten activities. According to Delphie Bandi (2009) reveals that "the sense of the concept or concepts referring to the planting base. Learners developing a concept when they are able to classify or group the objects and is able to associate a name with a particular group of objects ". According to Cople (2001:47) number is a symbol or a symbol that represents an object that consists of the numbers. For example, the number 10, may be written with digits 2 digits 1 and 0 . According to Tajudin (2008:23) number is the one tool that contains a single understanding. These numbers represent an amount that is manifested in the symbol numbers. 
The concept of numbers is an idea or design knowledge in understanding the collection of figures and ask the many members of the value of an object in mathematics (Inra: 2012). Is the unit numbers in the mathematical system can be operated mathematically (Sriwasito: 2008).

The number is one part of mathematics. According to Wasik\&Seefeldt (2008:329) one of the most important math concepts learned by early childhood which is about the concept of numbers. The concept of the number involves thinking about how the amount or how much including calculating and summing. Inawati (2011:4) argues that to know the concept of numbers in early childhood is the Foundation for math skills as well as readiness to follow basic education. If the basic concept of getting to know the concept of numbers given on early childhood less mature at a later stage, then the child will have difficulty in getting to know the concept of numbers.

Thus, it can be said that the concept of numbers is the Foundation of mathematics. Learn to know the numbers or the number of children you can do by way of counting through counting objects or objects with the concrete, of course how to count them more or less the same way as adults. The ability just by counting the objects one by one will be calculated accordingly. For example, one Apple, two apples, three apples, and so on. Introduce the concept of numbers usually can also by using existing images or from the surrounding environment. Understanding the factors that affect the number

1) The descendants of

hereditary factors which is bringing since birth or descent, such as the Constitution and physical structure, potential skills (aptitude and intelligence) every child is born with a set of potential. The potential of that basis will be developed to its full potential after receiving the stimulus from the environment. The process of acquisition through this device

2) Environment

The environment is very influential in the growth and development of the child. The family environment is nurturing and raising children, school places, educate communities where children hang out and play in environment around (nature).

3) Craze

Every child has a different attitude then favorite it from one another is also different that in the process education adapted to the child's interest and fondness.

4) Factor in The Ability of Teachers
Teachers can be interpreted as the person responsible for implementing the target with the student learning, by providing guidance to students in the physical as well as spiritual development, in order to achieve an optimum level of development.

5) Facilities and infrastructure Factors

The procurement of means and learning tools is a step the teacher or the school embodies the planning study has been made. As good as any planning was created as a learning resource, if the teacher does not manifest in the form of procurement, will not achieve optimum results

Base on explanation above it can be concluded that the concept of numbers represents numbers which can be conceived children through experience experienced by children. And an understanding of the concept of number evolved in accordance with the stages of child development which through methods and a good way of learning the methods of play.

Learning Media used must be able to attract the attention of a child on the teaching and learning activities and more stimulating learning activities. The media will be made of teachers as a tool and a learning resource must have a reference that is the purpose of teaching. There is a wide range of media that can be used in teacher learning activities, one of which is a media picture cards. Media Card is a simple media in the form of a card with a fitted image (pictorial cards), the pictures on the grouped cards, among others, to: a series of animals, fruits, clothing, color, and so on, the card is played and shown to the boy with the fast way to trigger the right brain working children receive information (Indriana, 2011:138). The teacher plays an important role in motivating students to teaching and learning activities more interesting and fun by using the appropriate media in supporting teaching and learning so that the material presented is more interesting and easy to understand. Thus, how to use media cards that can quickly help to maintain concentration tends to be low.

The Media is an intermediary or an introduction messages senderto recipient. According to Gagne (Sadiman, 2008) reveals that the media are the various types of components in the environment of students who can be stimulating to learn. Meanwhile Briggs argues that the media is any physical tools that can present the messages and stimulate students to learn. Benefits of media on learning activities, according to Kemp and Dayton, is as follows:

1) The delivery of the learning material can be equated.

2) The learning process becomes more attractive 
3) Learning becomes more interactive

4) The amount of time teaching and learning can be reduced

5) The quality of student learning can be improved

6) The process of learning can occur anywhere and anytime

7) Positive attitude students to learning process can be improved

8) The role of the teacher can change towards a more positive and productive

Another opinion states that the use of the media in the process of teaching and learning has practical value as follows:

1) Media learn can overcome various limitations of the student experience

2) Media enables direct interaction between students and the environment

3) Media can be embed the basic concepts, concrete, and reality

4) Media can stir up new interest and desire

5) Media can stir up motivation and stimulate students to learn

6) The Media can give you the experience of a concrete integral to the abstract.

Fadlillah (2012:205) reveals that the term is derived from the plural media medium, meaning intermediaries, additionally media also interpreted as something that lies at the core. The meaning is a gobetween that connects, and distinguish between the communication media and communication tools. Therefore, in terms of learning media is a tool that serves to convey information to the learners. Meanwhile, according to Marshal Mcluhan (Trianto, 2007:122) revealing that the media is aexistence of a man who allowed him to influence others who do not hold a direct contact with it.

Gerlach and Ely (in Azhar, 2011:3) reveals that the media when it is understood generally are human, material, or events that build conditions that make students to acquire the knowledge, skills, or attitude. The sense of the media in the process of teaching and learning tends to be defined as graphic tools, photographic, or e to capture, process, and rearranges visual or verbal information.

So, it can be inferred that the media is a tool that is used as an intermediate means to convey a message, so that the desired message can be read by precisely, easily, and accepted and understood as it should which does not hold a direct contact with it.

According to Sadiman (2003) "card (card) is a thick paper that is not how big the rectangular or square". The card is a little thin, flat object, generally made from thick paper or plastic and the number refers to a sign or symbol of number or mobile number. Picture cards is a card-picture cards that come with the emblem of the numbers or letters that are grouped in accordance with their respective series of images. The pictures with the blatant would be very frowned upon, according to Azhar Arsyad (2011) "Flash Card is a small card that contains images, text, numbers, or symbols in the sign that leads children on a related image. The benefits and usefulness of card numbers is as follows:

1) Knowing the concept of many little

2) The child can enumerate many a fine of one to ten

3) Get to know the concept of numbers

4) The child can recognize and mention the coat of arms of numbers 1-10

5) The child can match the right numbers with the symbol numbers.

At this stage, the learner is expected to know and show the coat of arms of numbers 1,2,3, 4 .5 .6 .7 $.8,9.10$. As for how to use the card numbers are as follows:

1) The card number used when learning takes place

2) Use the card at the time explained about numbers or it could be by the time the children learn counting

3) At the time of learning make a cozy atmosphere, thus arousing the learning motivation of children at

Let the children use to learn and recognize the symbol numbers through media cards illustrated figures. Based on the opinion of the above can be confirmed that the advantage card number and picture cards are as follows;

(a) the learning will be more easily understood because with the card the material will be easily repeated, so that the learning objectives can be achieved that is the understanding of the child can be achieved optimally;

(b) learn the symbol number by using numeric cards and picture cards, the child will glad because the card is packaged and presented with a theme that is varied and interesting;

(c) because of the relatively small forms card then the card can be stored in any place. Due to its practical then the material will be easy to learn where the child will learn them. The advantages of the card number and picture cards;

1) the form of a simple card 
2) card number and picture cards accompanied by figures and drawings;

3) the image used in the form of pictures objects with color interesting that the children often encountered in everyday life;

4) easy to learn and use so it is easy to get to know coat of arms of the number;

5) have the flexibility or practicality in its use.

By using the card number and picture cards as well as knowing the strengths in teaching and learning especially in learning to know the symbol number of the expected learners can enhance the ability to recognize the symbol numbers.

\section{CONCLUSION}

Learning is a process by which behavior is modified, justified or controlled. While the process of learning is an educational interaction between learners with other learning components. Learning in early childhood is obviously very different, because it has the principle of learning while playing, where the study was conducted in an atmosphere of fun play. One of the areas of the development of the KBM in PAUD field of cognitive development that is obtained through the activities, counting, enumerating, classify, recognize shapes, distinguish something and others. It aims to develop cognitive abilities related to develop the ability to think so that children acquire the lesson, can simulate various alternative problem solving, help the child to develop his mathematical logic ability and knowledge of space and time, as well as have the ability to sort, classify and prepare thorough thinking ability. Thus, the authors conclude that learning the concept of numbers by using a media card number is a method of learning that is highly effective and efficient for early childhood in the early stages of learning to understand numbers and counting.

\section{BIBLIOGRAPHY}

Arsyad, Azhar. 2011. Media Pembelajaran. Jakarta : PT RajagrfintoPersada.

Delphie, B. 2009. Matematika Untuk Anak Berkebutuhan Khusus. Klaten: PT IntanSejati.

Dwijawijaya, 2006. MengenalBilangan Dan AngkauntukTK.Yogyakarta :Kanisiu

Indriana, Dina. 2011. Alat Bantu Media Pembelajaran. Yogyakarta. DIVA press.
Fatimah. 2009. Pembelajaran Matematika Pada Anak Usia Dini Berbasis Multiteknik.

Fachrurrazi. 2012. Stategi Pembelajaran Anak Usia Dini. Surabaya: Universitas Adi Buana Surabaya.

Gunarti. W, Suryani, L, Muis, A. 2013 :Metode Pengembanga nPerilaku dan Kemampuan Dasar Anak Usia Dini. TanggerangSelatan :Universitas Terbuka.

Kilpatrick, J., Swafford, J., \& Findell, B. (2001). Adding it up: Helping children learn mathematics. Washington DC: National Academy Press.

Hurlock, Elizabeth. 1978. Perkembangan Anak. Jakarta: Erlangga.

Ikatan Guru Taman Kanak-kanak Indonesia, IGTKI. 2012. Pelangi IGTKI. Jakarta: IGTKI.

KurniawatiErmi, RohayahSiti. 2009. Math at Home. Yogyakarta: Media GrafikaUtama.

Masitoh, Dkk, 2007. Strategi Pembelajaran TK .Jakarta :Universitas Terbuka.

Sudaryanti. 2006. Pengenalan Matematika Anak Usia Dini. Yogyakarta: FIP UNY. 